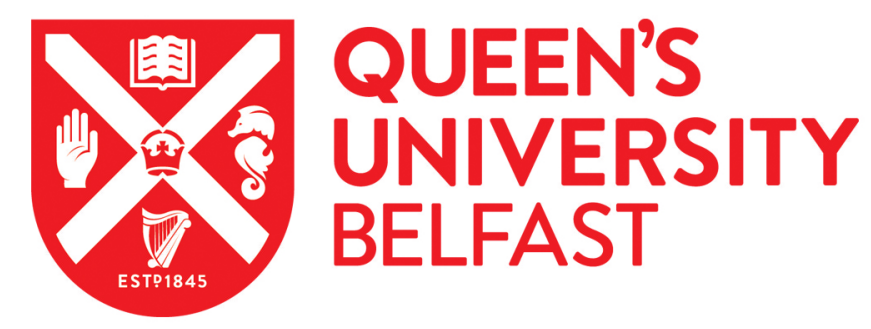

\title{
Social Exclusion, Equality and the Good Friday Peace Agreement: The implications for land use planning
}

Ellis, G. (2001). Social Exclusion, Equality and the Good Friday Peace Agreement: The implications for land use planning. Policy \& Politics, 29, No. 4(4), 393-411.

Published in:

Policy \& Politics

Queen's University Belfast - Research Portal:

Link to publication record in Queen's University Belfast Research Portal

\section{General rights}

Copyright for the publications made accessible via the Queen's University Belfast Research Portal is retained by the author(s) and / or other copyright owners and it is a condition of accessing these publications that users recognise and abide by the legal requirements associated with these rights.

Take down policy

The Research Portal is Queen's institutional repository that provides access to Queen's research output. Every effort has been made to ensure that content in the Research Portal does not infringe any person's rights, or applicable UK laws. If you discover content in the Research Portal that you believe breaches copyright or violates any law, please contact openaccess@qub.ac.uk. 


\section{Social exclusion, equality and the Good Friday Peace Agreement: the implications for land use planning}

Geraint Ellis

\section{English}

The Good Friday Peace Agreement has attempted to establish a constitutional settlement in Northern Ireland by trying to address the long-term causes of conflict in the region. While it primarily deals with the region's relationship to Britain and the Republic of Ireland, it also includes measures that tackle social exclusion and discrimination in policy making. The article examines the impact of these on land use planning in the region, which has traditionally adopted a centralised, technocratic approach to policy making that denied the realities of sectarian division. The new policy agenda directly challenges this style of planning and has included a number of initiatives that could partially open the planning system to public scrutiny and force it to incorporate issues of social justice.This article describes the partial success in implementing these measures and makes an interim assessment of their potential impact and broader policy relevance.

\section{Français}

L'accord du Vendredi Saint a tenté d'établir un arrangement en Irlande du Nord en essayant d'indiquer les causes anciennes à l'origine du conflit dans les régions.Alors qu'il traite principalement des rapports de la région avec la Grande-Bretagne et la République d'Irlande, il inclut également les mesures qui s'attaquent à l'exclusion sociale et la discrimination lors de l'élaboration des lois. Cet article examine leur impact sur le projet d'utilisation des terres dans la région qui a adopté traditionnellement une approche centralisée et technocratique législative qui refusait d'admettre les réalités de la division sectaire. Le nouveau programme politique conteste directement ce style de d'élaboration et a inclus un nombre d'initiatives qui pourraient partiellement rendre le système de législation accessible à un examen minutieux du public et le forcer à incorporer des questions de justice sociale. Cet article décrit le succès partiel de l'implémentation de ces mesures et donne une évaluation intérimaire de leur impact potentiel, et leur rapport avec la politique au sens plus large.

\section{Español}

El Acuerdo del Viernes Santo ha atentado establecer un convenio constitucional en el Norte de Irlanda intentando dirigir las causas a largo plazo del conflicto en las regiones. Mientras primeramente trata con las relaciones entre las regiones de Bretaña y la República de Irlanda, también incluye medidas que abordan la exclusión social y la discriminación en la elaboración de directrices generales. El artículo examina el impacto de todo lo mencionado en planear el uso del territorio en la región, el cual ha adoptado tradicionalmente un acercamiento centralizado y tecnocrático hacia la elaboración de directrices generales que negó las realidades de la división sectaria. La nueva agenda política desafía directamente este estilo de plan y ha incluido un número de iniciativas que podrían abrir parcialmente el sistema planeado al examen público y forzarlo para incorporar asuntos de justicia social. Este artículo describe el éxito parcial en el implemento de estas medidas y hace una evaluación parcial de sus impactos potenciales y una mayor ampliación de relación política. 


\section{Introduction}

In terms of public administration, Northern Ireland has been traditionally viewed as having little to offer wider policy debates, often seen as being preoccupied with responding to its unique political situation. However, as the peace process unfolds and with increasing efforts to 'normalise' Northern Ireland society, new opportunities are emerging for policy transfer to and from the UK and other parts of Europe. Of key interest in this respect is the Good Friday Peace Agreement ${ }^{1}$, which forms the basis of a political settlement that has, so far, delivered a period of stability and relative calm unseen in the previous thirty years. The critical elements of the Agreement dealt with the constitutional relationship of Northern Ireland with Great Britain and the Republic of Ireland, while establishing an arrangement for devolved power sharing in the region. The debate over whether the Agreement provides a basis for a long-term settlement will not be entered into here (see for example O'Leary, 1999 and Stewart, 1999), but instead the article will focus on other economic and equity issues that were introduced into the Agreement in an attempt to encompass other dimensions of division in Northern Ireland. One dimension of this is that the Agreement assumes that conditions of economic deprivation and socio-economic differentials are a contributory factor to the conflict and that by addressing these factors, the potential for violence could be reduced (Shirlow and Shuttleworth, 1999). During negotiations, these matters were seen as subordinate and less critical than the more fundamental constitutional issues, so that issues that would be seen as potentially radical and contentious in other policy contexts were included as relatively unproblematic parts of the Agreement (eg, creation of a Human Rights Commission). It is suggested here that the initial optimism attached to the Agreement allowed innovative measures to be adopted as part of the policy agenda of the Northern Ireland Executive and that this may provide some opportunities for policy transfer in a UK or wider context. Many of these issues have been endorsed through central government legislation, particularly the 1998 Northern Ireland Act, so that even if the Agreement were to falter and the Assembly to collapse, it is highly likely that these issues will continue to be pursued in a return to Direct Rule.

This article seeks to describe the measures that have been adopted to address issues of social exclusion and equality in policy making and will specifically examine how these issues are being incorporated into the field of land use planning ${ }^{2}$. During 'the Troubles', planning in Northern Ireland pursued a strategy of formal technocratic neutrality, which has left it poorly disposed to addressing the new pluralist policy agenda in the region and the broader discursive paradigm of 'collaborative planning' (eg Healey, 1997). As a result of the broader political developments in the region, planners in Northern Ireland find themselves having to incorporate issues of social justice into professional discourse, even if only rhetorically, for the first time in three decades. This therefore provides an interesting case study, not just for planners in other parts of Europe facing the same issue, but also for practitioners of other disciplines having to rapidly address new policy goals.

Initially, a review is given of the relationship between land use planning and the issues of equality and social exclusion, followed by a discussion of the nature of planning in Northern Ireland. A description is then given of the policy mechanisms used and the planning documents that illustrate the degree to which these policy goals have been able to influence this traditionally technocratic activity. The key focus of this study is the policy documents produced by the planning authority and, while there is an awareness of potentially deeper 'regimes of truth' (Foucault, 1980) that could be revealed through a discourse analysis of these texts (Hastings, 1999), the emphasis will be on their formal and rhetorical characteristics (Fairclough, 1995) and how these potentially relate to planning outcomes. Thus an attempt is made to contrast the ideals of inclusion and equality expressed in the Agreement with their practical interpretation in this single field of public policy. This will therefore reflect on some of the problems of implementation (Hogwood and Gunn, 1984) involved in the translation of political rhetoric into bureaucratic action (Barrett and Fudge, 1981).

It is recognised that such an analysis is constrained by two key factors. First is the fact that 
the new policy agenda that has emerged from the peace process is still in its infancy and that a full review of its impact on any one area of policy is only possible once the broader initiatives have 'bedded down' and been fully integrated into the region's bureaucratic culture. Within planning, this is likely to take a number of years, so that the findings given here can only really be seen as an interim assessment. Second is that the analysis presented here seeks to review these initiatives as they are reflected in formal policy documents, rather than the impact they have had on discretionary aspects of individual decision making. It is contended here that more depth research, based on interviews or observation techniques, would be most relevant once the full policy apparatus has been implemented.

\section{Social exclusion and equality in land use planning}

Social exclusion has become central to discussions of justice and social policy in Europe and the UK, as it has become accepted that it represents a more accurate way of portraying the multifaceted nature of disadvantage than the concept of poverty by focusing on the interdependence of the different processes contributing to marginalisation. Although academic debate has often focused on the contested nature of the concept (eg Room, 1995; Levitas, 1996; Byrne, 1999), a large body of literature is emerging that applies social exclusion to discrete fields of public policy (eg Lawless et al, 1998; Kitchin, 1998; Anderson and Sim, 2000). While related fields such as urban policy have absorbed the concept of social exclusion (eg Griffiths, 1998; Atkinson, 2000), statutory land use planning has paid little explicit attention to it, despite the fact that location and place play an important role in creating exclusion and reinforcing the barriers to inclusion (Lee and Murie, 1999). This antipathy to social issues needs to be located within planning's drift from being a movement for social reform to being a market-supportive bureaucratic process (Reade, 1987) and the conservative nature of the profession (Thomas, 1999).

Although there have been previous debates regarding the role of planning in addressing disadvantage (eg Eversley, 1990; Thompson, 1990) and the relationship of different excluded groups to the planning process (eg Thomas and Krishnarayan, 1994; Imrie, 1996), current debate regarding social exclusion has failed to have much resonance within the profession. Indeed, only two papers, those by Davoudi and Atkinson (1999) and Turok et al (1999) have attempted comprehensively to define planning's role in tackling social exclusion.

Davoudi and Atkinson (1999) define two elements in the relationship between planning and social exclusion. First is the function of the planning process, ie the ability of excluded groups to achieve access to decision making. While they acknowledge a range of initiatives to overcome deficiencies in participatory mechanisms, such as Planning Aid, they suggest that planning is generally dominated by a mode of corporatist governance that encompasses political, professional and business elites, but excludes wider community interests. The second issue they highlight is the relationship between social exclusion and the outcomes of planning, such as the access to amenities, services and quality of life.

This last issue is developed further by Turok et al (1999) who recognise that planning is not one of the principal causes of exclusion, but suggest it can reinforce and exacerbate the problem and, ergo, it has "a role to play as part of a broader effort to promote social integration and cohesion" ( $\mathrm{p}$ 363). By highlighting the value of its strategic outlook, regulatory responsibilities, coordinating ability and consultative experience, they identify the ways in which planning can contribute to a process of social inclusion. This includes addressing issues of uneven spatial development by influencing location of housing, employment and transport infrastructure or developing strategies to combat residential segmentation and social segregation. Furthermore, by improving public transport and enhancing the environmental quality of low-income areas, planning can support other economic development strategies and can help coordinate a multisectoral approach to social exclusion by facilitating participation, targeting priority areas, improving environmental quality and enhancing community safety. Turok et al (1999) essentially call for a reorientation of planning's objectives away from market-supportive land use regulation to one geared to achieving more 
socially defined goals. They further stress that there has been a tendency to focus initiatives at particular neighbourhoods and specific social groups, rather than penetrating mainstream economic, fiscal and social policies.

Although Turok et al (1999) tend to over-stress the spatial solutions to social exclusion at the expense of broader socio-economic approaches, they do usefully suggest how the spatial fetish of planning practice can be harnessed for, rather than against, social inclusion.

These two papers highlight three points that are salient to the Northern Ireland case study:

- The spatiality of exclusion has led to planning practices that aim to dismantle pockets of deprivation without either tackling the causes of deprivation (Madanipour, 1998) or addressing the ways in which planning outcomes reinforce exclusionary processes.

- Planning, or any other area of public policy, cannot effectively pursue a strategy of social inclusion on its own. By recognising that social exclusion is a dynamic and multidimensional phenomenon, we must accept that it can only be tackled in a strategic way through an integrated regional or national framework, where planning can provide a spatial expression and play a coordinating role.

- The political process of planning itself acts as a barrier to inclusion by hindering the formulation of policies that are sensitive to the needs and values of excluded groups. While the lack of participation in education and the labour market represent the most crucial fundamental forms of exclusion, a lack of access to decision making within other areas of public life, such as land use planning, can be seen as a part of a broader denial of citizenship rights (Berghman, 1995). These collectively combine to be an important element of the processes that contribute to social exclusion.

While this last issue of procedural justice makes up only one element of how planning relates to social exclusion, it is a fundamental one, for without greater involvement of excluded groups in the decision-making process, planning policies will either remain dominated by existing economic interests or will rely on a paternalistic profession making policy choices on behalf of the excluded. While these procedural issues should not override the ultimate outcomes of planning, it is important to note that planning currently gains much of its legitimacy from the notion of equal individual access to decision making, which is biased towards certain sections of society, such as those with property interests or an articulate middle class (Reade, 1987; Healey et al, 1988). Although these processes have not been fully articulated in terms of social exclusion, the causal effects are well documented. Indeed, Yiftachel (1995) has suggested that planning can even be used as an instrument of control by affecting the territorial expression of nonassimilating groups, socio-economic outcomes of policy and access to decision making by adopting exclusive procedural approaches. Thomas and Krishnarayan (1994) have also shown how the policy processes of British planning can accentuate disadvantage faced by marginalised groups. While such a situation may be viewed as an inevitable outcome of the social relations of western society, where capitalism, patriarchy and racism structure the uneven outcome of policy, there is some scope for self-reflection and action by the planning profession to mitigate such prejudice.

The rest of this article will focus on Northern Ireland and the way in which land use planning has attempted to accommodate, and be accommodated in, the regional strategy for equality that has emerged from the Agreement. This will generally cover the issue of social exclusion but, while not wishing to underplay the significance of the territorial and socio-economic outcomes of policy, will specifically focus on the issue of procedural justice. Prior to discussing specific policy initiatives, it is important to understand the context for planning and the particular problems of disadvantage experienced in Northern Ireland.

\section{Planning and social exclusion in Northern Ireland}

The planning system in Northern Ireland is broadly similar to that of other parts of the UK, but with a number of differences stemming from the region's distinctive political evolution that have implications for how social issues have been 
incorporated in planning. The most fundamental difference is that between 1972 and 1999, in an attempt to control the volatile political situation, all power was transferred from a devolved regional assembly to Westminster ${ }^{3}$. This meant that planning responsibility was centralised with the Department of the Environment (NI) ${ }^{4}$, with the local authorities' role reduced to a consultative one. Since 1996 all administrative planning functions have been the responsibility of the Planning Service, set up as an arms-length 'Next Steps' Agency. During Direct Rule a system was established where an internal board of professional officers made almost all development control decisions. This arrangement continues with devolution, although the decisions are now made on behalf of a locally elected minister, rather than the Westminster-appointed Secretary of State.

The centralisation of government functions in 1972 was perceived by the British government as a way of promoting stability and overcoming the sectarian discrimination of local authorities in the provision of services (Knox, 1998). In terms of planning, it has removed issues of religious bias, but left it politically isolated and professionally dominated. During the Troubles, land use regulation was maintained under difficult circumstances by resorting to a narrow technical definition of planning (Blackman, 1991; Bollens, 1999), supported by an appeal to a definable 'public interest', minimal public participation and domination of engineering-based solutions. The Planning Service has formally distanced itself from any involvement in politics and until recently has even refused openly to acknowledge the divided nature of society (Neill, 1998). The hegemony of technocratic detachment has led to the perception that plan- ning in the region was conspiratorial and insensitive to social needs, with Bollens (1999: 268) suggesting that "neutrality is associated with unequal outcomes, poor public perception, and ineffective upliftment of Belfast's economically deprived". As such, the participatory frameworks and professional outlooks adopted throughout this period denied the existence of minority groups and their individual needs, thus reinforcing the political barriers to inclusion.

This took place in a political situation where a large proportion of the Nationalist community questioned the legitimacy of any government intervention and where social exclusion and equality were central to the way in which this section of society conceived their relationship to the state. The region's problems of social exclusion are not therefore only underpinned by economic disadvantage stemming from deindustrialisation and peripherality, but also by the economic and social devastation caused by the unstable political situation. As a result, the region has fared well below the European average in many of the key social exclusion indicators, particularly long-term unemployment, ill health and dependency on state benefits (Democratic Dialogue, 1995) (see Table 1).

The overall picture of deprivation does, however, hide significant disparities within the region, with Catholic households tending to be more deprived, having higher unemployment rates, lower car availability, lower educational attainment, a higher percentage of renting and suffering from the worst health (Smith and Chambers, 1991; O'Reilly and Stevenson, 1998). As such, Northern Ireland has a society that is polarised along sectarian lines resulting in a number of specific planning problems related to social and economic deprivation such as distort-

Table I: Key social exclusion indicators

Indicator

EUI 5

120

100

130

Dependency rate* (1996)

Gross Domestic Product per head (EUI5=100) (1996)

Unemployment rate (\%)

Long-term unemployment as percentage of the unemployed (1997)

$\begin{array}{lrr}100 & 100 & 81 \\ 10.7 & 7.1 & 7.5 \\ 49.1 & 38.8 & 55.4\end{array}$

* Dependency rates are calculated as the number of non-active persons

(total population less labour force) expressed as a percentage of those active.

Source: Central Statistics Office, 1999 
ed land markets, blighted space and the need for the duplication of many urban services (Boal, 1996). In addition to Catholic/Protestant inequalities, other minority groups, particularly travellers, suffer acute forms of exclusion with high unemployment, low educational attainment, extremely poor living conditions (Irwin and Dunn, 1997) and high levels of prejudice (Connolly and Keenan, 2000). While much optimism is attached to the impact of economic growth as a 'peace dividend', Shirlow and Shuttleworth (1999) highlight the fact that the type of service industries that have been attracted to the region in the 1990s only widen the options for the socially marginalised from labour market inactivity to a low-paid job 'tossing burgers'.

The nature of deprivation has meant that equality and social exclusion have become an element in establishing a long-term peace settlement in the region, with many seeing social justice as a constitutional issue (Smith and Chambers, 1991). This means that the links between social exclusion and citizenship rights identified by Berghman (1995: 19) have added significance in the region, leading Teague and Wilson (1995: 92) to claim, “... effectively addressing social exclusion in Northern Ireland is, ultimately, about creating an inclusive citizenship". This suggests that the political processes related to social exclusion are critical to the future of Northern Ireland. Therefore, while the technocratic approach adopted by the region's planners may have been an appropriate response to the difficult political circumstances of the Troubles, it now seems incongruous to a situation where reconciliation and the development of a cohesive society are the key political objectives.

\section{Planning and the peace process}

The political terrain of Northern Ireland has changed dramatically since 1994, when the IRA and Combined Loyalist Command declared ceasefires, formalising the current peace process. This culminated in the Agreement signed by the British and Irish governments and the main political parties in April 1998. The Agreement was overwhelmingly endorsed in referenda in both Northern Ireland and the Republic of Ireland and has the following main provisions:
- establishment of an Assembly and Executive to discharge the functions undertaken by the Secretary of State;

- amendment of the Constitution of the Republic of Ireland;

- an accelerated programme for the release of prisoners sentenced for terrorist offences;

- a programme of decommissioning by the paramilitary organisations;

- independent reviews of the policing service and criminal justice system;

- creation of an independent Human Rights Commission;

- establishment of a British-Irish Council, creating links with other devolved assemblies of the UK; and

- creation of a North-South Ministerial Council to bring together representatives of Northern Ireland and the Republic of Ireland on matters of mutual interest.

The Agreement has established the potential for a long-term political settlement (O'Leary, 1999) and while devolution was initially frustrated by the sequencing of decommissioning and not ignoring the growing Unionist unease regarding the outcomes of the peace process, most elements of the Agreement are now being implemented. The wide scope of the Agreement has meant that the peace process has been attached to a whole range of potential outcomes for Northern Ireland, not least being the opportunity to rebuild civil society (Morison, 1999) and reverse the region's economic misfortune (Department of Economic Development, 1999).

While these factors alone will exert pressures for changing the planning in the region, the Agreement has a number of direct ramifications for the planning system. This includes the return of political control of planning responsibility from Westminster to the Northern Ireland Executive, which has the power to delegate responsibilities further to local government. In order to facilitate ministerial representation for all the main political parties, government in the region has been reorganised into 10 departments, each with a minister in the new Executive. This has meant that planning responsibilities have been split between two departments, potentially causing difficulties in policy coordination and implementation. Regulatory functions (such as 
development control and development plans) come under the jurisdiction of the new Department of Environment (DoE (Northern Ireland $[\mathrm{NI}]$ ), while regional planning and transport fall under the Department of Regional Development (DRD). This has potentially created problems of coordination between the realms of planning, urban policy and transport, especially since the Democratic Unionist Party, who currently hold the DRD brief, refuse to sit in the Executive with the representatives of Sinn Fein. The Agreement has also established formal arrangements for cross-border cooperation on planning-related fields such as agriculture, urban and rural development, transport, environmental protection, waterways and tourism. The Agreement also specifically calls for new regional development and economic strategies for Northern Ireland, with the former emerging as the draft Regional Strategic Framework (DoE[NI], 1998) and due to be published in final form in the summer of 2001. This has placed a strong emphasis on generating views from all sections of Northern Irish society and employed a consortium of academic and community organisations to manage the consultation process (McEldowney and Sterrett, 2001), although this is not without its critics (Neill and Gordon, 2001).

The Agreement therefore not only establishes a mechanism for political reconciliation, but also makes an attempt to overcome some of the causes of the conflict in Northern Ireland. It includes a number of broader provisions that attempt to address the long-standing alienation between the state and civil society and which will have a strong influence on procedural equity and social exclusion in the region. These measures emerged as a result of pressure exerted by the voluntary sector in what has been described as "the parallel peace process" (Holland, 1998: 16). While this was developed to meet the specific demands of the situation in Northern Ireland, it addresses key issues of social justice identified as concerns to policy makers further afield. Two initiatives are of particular interest: first, a new statutory obligation to promote equality in policy making and second, a commitment to target government resources and activity towards the socially excluded. While both these initiatives have antecedents in previous Northern Ireland initiatives, they have now been placed on a statutory footing and have been amended to take account of the human rights agenda and social exclusion focus propounded by the Blair government. While these measures have relevance to many areas of public policy, the specific impact on the regulatory function of land use planning will be discussed here.

\section{Equality in policy making}

Since 1987, the UK government has made a number of attempts to overcome sectarian bias in the policy process in Northern Ireland (Cormack and Osborne, 1991; Knox and Hughes, 1994). The flagship initiative has been Policy Appraisal and Fair Treatment (PAFT), which came into force in 1994 with the aim of ensuring those issues of equality would be fully integrated into policy making and implementation at all levels of government (CCRU, 1995). This approach evolved from a UK-wide initiative to "equality-proof" all government policy on "race" and gender, tailored to the specific circumstances of the region (Osborne et al, 1997) and imbibed with high expectations that emerged from widespread consultation and an accompanying redefinition of spending priorities (Quirk and McLaughlin, 1997). Although the PAFT Guidelines were initially aimed at protecting the Catholic minority, they became more inclusive and protected groups distinguishable by religion or political opinion, gender, age, ethnic group, disability, marital status and sexual orientation. Under PAFT, government departments, agencies and quangos were required to appraise new and existing policies (when being reviewed) in terms of the impact on these groups. Where a differential impact was identified, departments were required to decide whether it was justified and consider alternative options.

However, it soon became clear that the nonstatutory basis of the PAFT was not enough to induce the anticipated shift in government policy and bureaucratic culture. Osborne et al (1997) found that while PAFT had been important in addressing the traditional mistrust of the civil service, it was criticised over its 'advisory' status, the availability of data to evaluate and monitor policies adequately, the way in which PAFT methodology was adopted in some departments and the level of resources given to ensure 
implementation. There was concern that PAFT was perceived as being a gesture rather than a full commitment to equality. The impact of PAFT on planning has been reviewed by Ellis (2000), who found that the DoE(NI) took a minimal approach to appraising its activities and casts doubt on whether there was any positive impact on planning policy.

As a way of reinvigorating equality measures in Northern Ireland, the incoming Labour government proposed a number of initiatives in a White Paper in March 1998 (NIO, 1998). These were endorsed in the Agreement, which established 'mainstreamed' equality measures that some have suggested surpass the rest of the UK and most of the world (McCrudden, 1999; Mageean and O'Brien, 1999). These measures were formalised in the 1998 Northern Ireland Act, which established a Northern Ireland Human Rights Commission (Livingstone, 1999), a new Equality Commission ${ }^{5}$ and, most significantly here, created a statutory duty on public bodies ${ }^{6}$ to have:

due regard to the need to promote equality of opportunity -

(a) between persons of different religious belief, political opinion, racial group, age, marital status or sexual orientation;

(b) between men and women generally;

(c) between persons with a disability and persons without;

(d) between persons with dependants and persons without. (Section 75(1))

In carrying out their functions, public authorities must also "have regard to the desirability of promoting good relations between persons of different religious belief, political opinion or racial group".

This replaces the advisory PAFT Guidelines and provides a strong framework for equality in all areas of public policy, including land use planning. This is enforced by requiring every public body to producing an 'Equality Scheme' stating how it will fulfil the new duties, including a timetable of actions and provisions for staff training (Equality Commission, 2000). Public bodies have to assess the impact of all existing and proposed policies on the equality of opportunity of each of the specified groups. Where it is consid- ered that a policy may have significant implications for equality, it should be subject to a detailed 'community impact assessment'. These are based on the concept of environmental impact assessment, with a similar emphasis on anticipating effects and public participation, with full consultation with those likely to be affected. The Guidelines stress that this should be based on active participation in the formulation of policy and should be enshrined in an annual consultation plan.

Each public body submits its Scheme to the Equality Commission, who then is able to approve it, request revisions, or replace it with a Scheme of its own. The Equality Scheme will have to be reviewed within five years, with annual statements of progress.

A detailed analysis of what these provisions may mean for planning is given later in this article, but an optimistic account of the significance of the measures has been given by McCrudden (1999: 1704) who highlights their uniqueness in two respects. First is that they are underpinned by firm legal foundation, rather than being a matter of policy and thus sidelined against other departmental objectives. Second is that they integrate a wide range of equal opportunities into policy making, not just those of gender or race, as has been the experience with comparative measures in other countries. This has created expectations that go far beyond those engendered by the PAFT initiative, leading one commentator quixotically to claim that they have:

the potential to establish the foundations of a society where participation in a public civic space can take place in conditions of real equality and where unjust differentials in power, from what ever source, public or private, can be addressed in an emancipatory project, which may have tremendous resonance world-wide. (Morison, 1999: 1626).

Government departments submitted their Schemes to the Equality Commission in June 2000, allowing an initial assessment of whether such idealism can be justified. The Equality Scheme represents the first stage in meeting the new equality responsibilities by setting out the ways in which the public bodies will develop 
these commitments and identifying those policies which they deem appropriate for the more detailed equality impact statements. Statements from three equality schemes are of relevance to land use planning, those of the Department of Regional Development (DRD, 2000), the Department of the Environment (DoE[NI], 2000), and the Department of Social Development (DSD, 2000) that covers urban regeneration, community development and housing.

The three schemes take a standard format that closely follows the guidance issued by the Equality Commission (Equality Commission, 2000). As such they all make firm commitments to establishing the appropriate internal arrangements for meeting the new statutory obligations by identifying clear lines of accountability, identifying officers responsible, ensuring appropriate training for staff and committing resources to the new responsibilities. One of the most significant elements of the equality schemes is to show how each department has screened each of its policy areas for its impact on nine different groups ${ }^{6}$. Although the screening procedure has had to be done rapidly and most departments used a very mechanistic procedure for sieving policies, it represents an important indication of the extent to which the departments understand the social and economic effects of their policies and the significance of the equality legislation. Perhaps not surprisingly, given the focus of policy, the Department of Social Development (DSD) shows far greater awareness of the distributive impact of its policies than the other two departments which have been dominated by a technocratic approach to policy. Unfortunately none of the departments describes methods to screen their policies although the resulting assessment shows that the DSD has taken a comprehensive approach, stating that almost all their policies will have some equality effect and will thus be subject to more detailed equality impact statements. In contrast the DRD and DoE(NI) take a more restricted view, reflecting their previous "colour blind' approach to issues of disadvantage (Ellis, 2001). In the case of the $\operatorname{DoE}(\mathrm{NI})$, they fail to recognise the potential of indirect discrimination in development control and to a lesser extent, development plans, despite established evidence to the contrary (eg Greed, 1994; Thomas, 1994; Imrie, 1996). Where the potential for discrimi- nation has been recognised, it has tended to be in terms of the old equality agenda (ie religion) rather than the new social exclusion agenda that encompasses a wider range of groups. This reflects the lack of experience on behalf of these departments, who need to undertake specific research and learn from comparative studies of models of best practice elsewhere. The weakness of the schemes has been highlighted in voluntary sector responses (eg CTA, 2000) to the consultation exercises. The fact that around 150 draft equality schemes were available for consultation during a six-week period, however, placed a great strain on many voluntary bodies that responded to them strategically, rather than comprehensively, and were given no additional resources or capacity building to undertake the task.

The equality schemes are required to set out a schedule for taking action on the identified equality issues and prioritise each action against a set of criteria that includes the impact of social need and availability of resources. While the DSD appears to have prioritised against need criteria and thus places an assessment of the benefits and direct service provision as a priority, the timetables of the other two departments appear to have adopted existing work programmes irrespective of impact on equality. Thus the DRD delays the assessment of regional planning policies until the last year of the action plan, despite the disproportionate impact this would have on all the department's activities. Similarly the DoE(NI) has reiterated its adopted development plan schedule rather than target those areas with greatest social need, such as Belfast. Finally, the equality schemes must provide details of how each department will monitor the equality impact of all of its policies. This is an area of some novelty to these three departments and while they make a commitment to developing more effective monitoring mechanisms, they are not well developed, despite available models of best practice (eg Riley, 1994; Loftman and Beazley, 1998).

At this stage in the process, it is only possible to make a precursory assessment of the impact of the new equality schemes on planning practice in the region. The real impact of such measures can only really be effectively evaluated several years from now when planning policies have been comprehensively adjusted and 
implemented along equality lines. While some of the teething problems have been highlighted, the potential of such an approach is extensive, with, for example, equality potentially becoming a material consideration in every planning decision. Although the status of such issues will have to be tested in the courts, this illustrates the impact this could have on planning in the region. This needs to be balanced with the fact that it would be wrong to portray the equality duties as a panacea for all social injustices in planning. The new equality duties are not aimed at delivering a more just outcome of every planning decision, but have the objective of establishing procedural equality where decisions are made in a way that does not discriminate against any group in society, distributive impacts are evaluated and where any decision can be challenged. This formal recognition of inequality is a major condition for social justice and, if fully embraced by the agencies involved in planning in Northern Ireland, could create the transparency and accountability that could give rise to a very different planning system to that in Britain.

The broader significance of these new measures will be assessed later in the article, following a description of a second initiative recently introduced in Northern Ireland, aimed at addressing social exclusion.

\section{New Targeting Social Need}

When the British Government introduced the concept of equality into policy in Northern Ireland, it was accompanied by an attempt to target public resources on areas and people in greatest need. Known as Targeting Social Need (TSN), this initiative was launched in 1991 as a third government expenditure priority for the region, alongside law and order and economic development. As with PAFT, the introduction of the initiative generated high expectations for a more socially orientated approach to public policy in the region, but was equally dogged by ambiguity and lack of implementation by government departments. Although TSN did give rise to a number of important urban policy programmes such as Making Belfast Work (Birrell and Wilson, 1993), it failed to make any significant impact on policy making within government depart- ments (Osborne, 1996; Quirk and McLaughlin, 1997), leading to the conclusion that:

The TSN policy is potentially the most significant policy initiative in the area of social need, deprivation and disadvantage ever taken by Government. However, it has yet to take root in all Departments or to make real impact where it is most needed...Unless Government establishes new ways of progressing the policy and of challenging Departments to implement it with vigour and enthusiasm it may unfortunately remain a nice idea existing in the margins of Government and the minds of a few committed individuals. (NICVA, 1996: 6)

The evolution of the initiative has followed a similar path to that of PAFT in that following growing criticisms, it underwent rehabilitation by the incoming Labour government, which set out its proposals for the reform of TSN in the same White Paper as the new proposals for PAFT (NIO, 1998). These proposals were then endorsed in the Agreement and launched in November 1999. The initiative was remodelled along classic Blairite lines, in that it was renamed New TSN and incorporated the familiar discourse on social exclusion and participation. The initiative has three key elements of focusing on unemployment, addressing social needs such as poor housing conditions and coordinating the actions of government departments to tackle social exclusion (New TSN Unit, 1999). This last element, known as Promoting Social Inclusion (PSI) has identified initial priorities as being needs of ethnic minority groups (especially Travellers), problems of teenage parenthood and identifying ways in which services can be made more accessible.

As a way of mainstreaming this policy, each government department is required to produce an action plan setting out exactly how it intends to meet these responsibilities over the next three years (New TSN Unit, 1999). Planning has been split into two 'business areas', regional planning and land use planning. The relevent departments (the DRD and the DoE[NI]) take what can only be described as a minimalist view of their contribution to the social exclusion strategy and the 
action plans of both can be interpreted as simply accommodating previous practice under existing work programmes. Both departments aim to tackle the "accessibility of jobs, housing, social amenities and a quality living environment" (New TSN Unit, 1999), with the DRD suggesting the only outcome will be a Regional Development Strategy that 'meets social need'. For the $\operatorname{DoE}(\mathrm{NI})$ the key outcome is limited to ensuring there is enough land 'to facilitate development conducive to meeting social need'. Neither defines what they mean by social need and if this is the main planning outcome of the New TSN initiative one must wonder whether there is any added value - prior to the initiative did they ignore 'social need'? Furthermore the more specific targets or actions that need to be stated in the action plans are equally disappointing, generally amounting to taking TSN into account when preparing future policy. The action plans of both planning departments tend to suggest only minor tinkering with existing policy areas, rather than the more fundamental reorientation of policy objectives or budget reallocation that is required by the New TSN rhetoric.

Any analysis of these documents can only conclude that they consist mainly of a reiteration of the conventional wisdom of modernist planning discourse clad in platitudes of achieving social inclusion. It would seem the departments have no conception of the spatiality of social exclusion and their response to the corporate initiative must be seen as having dubious value. At a very basic level this response must be compared to the possibilities outlined by Turok et al (1999), discussed earlier. They suggest a number of ways in which the outcomes of planning can be influenced to assist social inclusion strategies, yet none of these are taken up by the DRD or DoE(NI) and areas in which planning could make a positive contribution remain unexplored. Therefore, critical issues such as coordinating the demand for labour with the location of employment-generating development are ignored along with issues such as the way planning services are delivered, integration with other departmental strategies, methods of participation or allocation of internal budgets.

It is suggested here that the overall government approach to social exclusion in Northern
Ireland still remains a sound and innovative initiative, but it is failing, at least in the case of planning, through major implementation deficits. These include the fact that planning has long been dominated by a mindset focused on delivering impartial regulation of land use, with minimal social input. These initiatives were accompanied by minimal staff training and no additional resources so have had to be addressed at the expense of existing statutory requirements. Furthermore the structure of government in Northern Ireland is different from other parts of the UK in that a different political party controls each ministry, with only minimum collective responsibility. Therefore the New TSN initiative falls short of 'perfect implementation' on a whole range of issues including those of a lack of resources, a complex pattern of dependency relationships, ambiguity over objectives and an absence of authority to demand compliance (Hogwood and Gunn, 1984). It is therefore somewhat ironic that the political situation that allows potentially radical measures to be introduced into the policy programme of the Northern Ireland government should also frustrate its implementation through the unique political and administrative structures needed to support it.

\section{Reflecting on the approach to equality and social exclusion}

In order to focus on the opportunities for policy transfer, the difficulties of implementation within the realm of planning will be put to one side for a moment and instead this section will focus on some of the more positive elements of the overall approach to tackling inequality and social exclusion. Both initiatives have emerged from a bold constitutional settlement that gave these issues higher status than that seen in other parts of the UK. Unfortunately, the implementation of these initiatives has faced rather predictable obstacles that do not inspire confidence that they will ultimately deliver what has been promised. Despite this, it is useful to acknowledge that both the equality provisions and the social exclusion initiative represent the first attempt in the UK to provide a government-wide approach to tackling these problems and it is suggested here that it is worth reflecting on the 
experience, to inform further development of such policies in Northern Ireland and beyond. As such, one could claim that the Northern Ireland initiatives offer the following positive lessons.

\section{The importance of mainstreaming}

One critical difference to all other approaches to inequality and social exclusion is how both objectives have been 'mainstreamed' ${ }^{8}$, in an attempt to make them a normal part of the policy process, rather than being an afterthought. Such an approach "entails a paradigm shift in thinking towards the development of policy and practice" (Rees, 1998: 194), as it seeks to identify the unrecognised ways in which policy processes are biased towards particular interests. Mainstreaming has its origins in attempts to integrate gender issues in international institutions such as the World Bank, but has emerged as a transnational trend following its promotion by the European Union (EU) (McCrudden, 1999). As suggested earlier, the case of Northern Ireland is unique in that it goes beyond gender and is underpinned by firm legal foundation. It is also unique in that it appears to be the only example where an attempt has been made to mainstream both equality and social exclusion into planning practice, thus attempting to prevent these issues being sidelined by other departmental objectives.

\section{The politics of difference}

The new measures implicitly assume that public policy will have a differential impact on each section of society and that the needs of minority groups should be considered and addressed in policy. This amounts to a rejection of the old model of a unitary public interest and recognises that there are "multiple publics" (Sandercock, 1998: 197). This is a fundamental tenet of a 'politics of difference' and a basic precondition for establishing the patterns of social justice and accommodation of diversity envisaged by Young (1990). This represents a radically different way of evaluating the costs and benefits of public policy, with the distribution of outcomes being assessed alongside traditional policy objectives.

\section{Proactive approach to equality}

It is fundamental to the equality provisions that public authorities will have to anticipate the potential impacts of policy on a wide range of disadvantaged groups and integrate remedial mechanisms when policies are formulated. This is potentially radical, as issues of inequality will have to be considered as part of the decisionmaking process rather than being accepted as an unintended consequence of policy implementation. While existing UK equal opportunities measures are negative and aimed at tackling discrimination, the equality obligations measures concentrate on proactively advancing equality itself. The identification of the potential impacts of policy then establishes a clear agenda for discussion and negotiation between state and civil society over the relative merits of different policies.

\section{Formal monitoring mechanisms}

In addition to the anticipatory provisions, the new measures also require the establishment of mechanisms to monitor any adverse impact of policies. This provides a retrospective check on the effectiveness of equality and social exclusion provisions, which will help identify whether a policy results in any discrimination and can help identify the actions needed to overcome any discrimination identified. The importance of monitoring has been stressed in relation to multiculturalism in British planning (CRE/RTPI, 1983; RTPI, 1993; Loftman and Beazley, 1998).

\section{Extensive participation}

The social exclusion and equality provisions make it mandatory for public authorities to identify and negotiate with those groups adversely affected by policies, which adds a further unique element to these initiatives. This should provide an opportunity for the groups themselves to articulate their needs, potentially allowing the assertion of specific dimensions to policy, such as those related to ethnicity (Fenster, 1996). This may ultimately force planners to shift from regarding issues of disadvantage (such as disabled access) as technical matters or exotic demands to viewing them as acknowledged rights. 


\section{Culture of affirmative action}

Equality in the UK has traditionally been encouraged by the 'soft' voluntary system of positive action, rather than the 'harder' affirmative action mechanism adopted in countries such as the US (Teles, 1998). Northern Ireland was an exception within the UK in that the government has adopted much stronger fair employment legislation, more akin to that of the US, but based on religion rather than discrimination on gender or 'race' (McCrudden, 1986; Sheehan, 1995). While this stronger stance has been accepted as a reaction to the widespread existence of sectarianism, the new equality provisions encompass broader equality issues.

\section{Statutory status}

The final significant attribute of the Northern Ireland initiatives is that in the case of the equality provisions, they are established as legal duties of every public authority and therefore open to enforcement and judicial challenge if not adequately applied. This goes way beyond previous equality approaches adopted as policy rather than law, to which exceptions could inevitably be made. Furthermore, the mandatory nature of the provisions may go some way towards addressing the reluctance of some authorities to adopt equality policies as a result of financial constraints, competing priorities or differences in internal culture (see Loftman and Beazley, 1998). The effectiveness of this is clearly seen by comparing the equality provisions, which have strong legal backing, with the social exclusion initiative, which retains a high level of departmental policy discretion and suffers as a consequence.

Together these represent a major practical and theoretical challenge for planning in Northern Ireland, that if ultimately successfully implemented may create a planning system that is significantly different from the rest of the UK. Unfortunately, for a number of reasons, these initiatives have not yet been fully reflected in planning practice, leading to the identification of a number of drawbacks.

\section{Implementation deficits}

The political and administrative structures of devolved government in Northern Ireland are currently constructed to maintain the power-sharing balance of the Executive, rather than to facilitate corporate implementation of policy. Therefore, while a major effort has been made to improve the implementation mechanisms of previous initiatives (such as PAFT), there is still significant scope for the initiatives to become lost within the discretionary scope given to individual departments.

\section{Participation burnout}

In establishing extensive duties of consultation for both New TSN and the equality provisions, substantial pressure has been placed on the voluntary sector to respond to these initiatives within a short timescale. Over 150 public bodies issued Draft Equality Schemes within a six-week period, with some voluntary organisations, such as Disability Action or the Traveller Movement, expected to respond to all of them. No capacitybuilding, training or additional resources were provided to the voluntary groups to undertake this task, leading to a lowering of both the quality and quantity of responses from the voluntary sector.

\section{Cross-departmental cooperation}

While there is an emphasis on tackling inequality and social exclusion in a strategic way through the preparation of New TSN action plans and Equality Schemes, this seems to have focused coordinating efforts within departments, with little effort at cross-departmental coordination. This has come at a time when departmental structures have undergone fragmentation to accommodate political representation. There is the potential for significant synergy to be gained from more 'joined-up government', particularly in the field of social exclusion, but as yet there is little evidence that this is successfully being achieved in Northern Ireland. 


\section{Lack of 'soft infrastructure'}

There may be a danger in over-reliance on the formal procedures described here, rather than achieving change through negotiation and reorganising government to facilitate more democratic and open decision making. The 'soft infrastructure' of governance (Healey, 1997: 200) that encompasses a relationship of consensus between state and civil society can be vitally important in overcoming social exclusion and marginalisation. At present the public bodies have treated the new equality and social exclusion duties as a conventional bureaucratic function, yet if real change is to be achieved more fundamental reorientation in work practices needs to be introduced.

\section{Old wine?}

The equality duties and New TSN are both strengthened versions of previous discredited policies, reworked to take account of the political priorities of the Blair government. This may therefore cast some doubt on whether they are truly fit for the new purposes assigned to them and whether they can overcome the credibility deficit associated with their antecedent policies. As such the situation in Northern Ireland could be seen to resemble the situation portrayed by Atkinson (2000: 1043), where social exclusion initiatives in urban policy appear to be a continuation of old 'poverty' measures extended in the hope of hitting the new social exclusion objectives to provide the impression that governments are doing something to address the newly identified problems.

\section{Avoidance of critical issues}

Both the equality schemes and New TSN action plans require government departments to detail the measures they will take to meet the various policy objectives. What is common to both initiatives is that departments have tended to include only those areas of policy that can be adjusted with relatively little bureaucratic upheaval (such as adjusting development control guidance notes) while avoiding more influential areas such as major budget allocations or the methods used for public participation.

\section{'Black box' screening}

A key process in developing both the draft equality scheme and New TSN action plans has been a screening of policies that will be subject to more detailed assessment. In both cases the criteria and method used to screen policies remain unclear and were not subject to consultation. Many of the key decisions had therefore been made before the public were allowed to comment, potentially focusing the consultation on less contentious issues and not complying with the rhetoric of transparency that accompanied the launch of the two initiatives.

\section{Department capacities}

The two initiatives described in this article have been progressed to meet the objectives of the peace process and as such may have proceeded at a rate beyond the department's bureaucratic capacities. Tight timescales were set for the publication of the draft equality schemes and New TSN Action Plans and departments were not given any additional resources to meet these new duties. Given the lack of experience of social issues and the change in internal cultures that is required to meet the new obligations fully, it is not therefore surprising that they do not meet the expectations generated by the rhetoric surrounding the initiatives.

\section{Conclusion}

The above comments are essentially based on a reformist view of what the current state apparatus could do to acknowledge its role in addressing inequality and social exclusion. Clearly, if one subscribes to a more materialist view of exclusion, such as that of Levitas (1996) or, in the case of Northern Ireland, Shirlow and Shuttleworth (1999), one would draw more pessimistic conclusions regarding the initiatives discussed and perhaps suggest the need for a more fundamental approach to influencing the patterns of wealth and power in Northern Ireland. This ultimately raises more profound issues than have been addressed here, brings the debate back to the more fundamental questions of whether social exclusion is a valid or useful concept and questions the role of the state in a liberal/bour- 
geois democracy. While acknowledging the importance of such questions, this article has sought to describe a number of interesting policy initiatives that have recently emerged in Northern Ireland and attempted to make an interim assessment of their value on the basis of the rhetoric attached to the Good Friday Peace Agreement, by specifically examining their impact on land use planning.

This assessment found that while the initiatives aimed at addressing social exclusion and promoting equality included a number of innovative elements, as yet they have not facilitated the full potential of land use planning in tackling these issues. It was noted that it is somewhat ironic that the political climate of the peace process that has allowed these issues to emerge on the policy agenda has also necessitated an administrative structure that frustrates the process of implementation. Thus, so far the initiatives that on paper appear to be radical policy approaches to equality have floundered because of the internal culture and capacities of individual departments. This may be partly due to the assessment being premature, but it is already clear that, particularly in terms of social exclusion, the initiative lacks the resources, structures and professional expertise to facilitate successful implementation.

The initiatives are, however, significant in that they provide a bureaucratic mechanism for addressing social issues through the planning system, something that has been long called for (Reade, 1987; Colenutt, 1997; Thomas, 1999). There are few comparative examples of attempts by planning authorities to tackle equity, with any UK examples tending to emerge from locally based radical political agendas, which have ultimately faced difficulties because of central legislative constraints on planning (eg GLC, 1985; Thornely and Montgomery, 1990). The peace process in Northern Ireland is different in that it has begun with legislative changes, which have coerced planners into tackling procedural inequality as part of the statutory land use planning system. Thus the main issue of significance here is that planning is required as a matter of government policy to reflect on the contribution it can make to tackling social exclusion and inequality and to embed this into its main policies and administrative procedures. This is a very different approach than that currently adopted in the rest of the UK where social exclusion is currently given scant attention in the regulatory planning system ${ }^{9}$ and where the key social exclusion strategies allocate planning a minor role (Social Exclusion Unit, 2000). Overcoming social exclusion does, however, require a large number of actors making long-term, coordinated commitments. While planning will not be central to the main thrust of social exclusion policy, both Turok et al (1999) and Davoudi and Atkinson (1999) have shown that it can make a positive contribution and there are strong grounds for proposing social exclusion as a more important element in guiding future planning practice. While it is clear that only limited social change can be achieved by tinkering with policy processes, procedural equality can be a prerequisite for achieving more far-reaching reform and, by empowering civil society, highlighting the structural issues that also need to be addressed. The peace process has established an administrative infrastructure through which this could potentially be influenced and, if fully and sincerely implemented, could begin to create a new approach to tackling inequality and social exclusion. While planning in Northern Ireland has not yet fully adjusted to this reality, it now has strong government backing to adopt such a role and in turn could help to consolidate the current peace process.

\section{Notes}

${ }^{1}$ Agreement reached in the multi-party negotiations, 10 April 1998 (hereinafter referred to as 'the Agreement').

${ }^{2}$ In particular, this refers to the relatively narrow process of regulating land use, rather than broader issues of spatial development that includes urban regeneration, housing and transport policy.

${ }^{3}$ Direct Rule lasted until December 1999 when there was devolution to a Regional Executive and Assembly. A failure to agree on decommissioning of arms resulted in the suspension of the devolved institutions in February 2000. Devolution was restored in May 2000 and the new 
institutions are currently functioning as set out in the Agreement.

${ }^{4}$ The political structures set up as part of the peace process has established a new Department of Regional Development that has taken on a number of planning related functions.

${ }^{5}$ This has taken over the functions of all the existing equality organisations including the Commission for Racial Equality (NI), Fair Employment Commission for Northern Ireland (dealing with discrimination on grounds of religious or political belief), Equal Opportunities Commission for Northern Ireland (gender or marital status) and the Northern Ireland Disability Council (disability).

${ }^{6}$ This includes Northern Ireland Government departments such as the DoE (NI), local authorities, quangos and UK-wide central government departments that are active in Northern Ireland.

${ }^{7}$ This includes religious belief, political opinion, racial group, age, marital status, sexual orientation, gender, disability and being with or without dependants.

${ }^{8}$ This has been defined as "the (re) organisation, improvement, development and evaluation of policy processes, so that $\mathrm{a}[\mathrm{n}]$... equality perspective is incorporated in all policies at all levels and at all stages, by the actors normally involved in policy making" (Council of Europe, 1998).

${ }^{9}$ The only guidance on this is in para 4.13 of PPG12: Development plans (DoE, 1999).

\section{References}

Anderson, I. and Sim, D. (eds) (2000) Social exclusion and housing: Context and challenges, Coventry: Chartered Institute of Housing.

Atkinson, R. (2000) 'Combating social exclusion in Europe: the new urban policy challenge', Urban Studies, vol 37, no 5- 6: 1037-55.

Barrett, S. and Fudge, C. (eds) (1981) Policy and action, London: Methuen.
Berghman, J. (1995) 'Social exclusion in Europe: policy context and analytical framework' in G. Room, Beyond the threshold, Bristol: The Policy Press: 10-28.

Birrell, D. and Wilson, C. (1993) 'Making Belfast work: an evaluation of an urban strategy', Administration, vol 41: 40-56.

Blackman, T. (1991) Planning Belfast, Aldershot: Avebury.

Boal, F.W. (1996) 'Integration and division: sharing and segregation in Belfast', Planning Practice and Research, vol 11, no 2: 151-58.

Bollens, S.A. (1999) Urban peace-building in divided societies: Belfast and Johannesburg, Boulder, CO: Westview Press.

Byrne, S. (1999) Social exclusion, Buckingham: Open University Press.

CCRU (Central Community Relations Unit) (1995) Policy appraisal and fair treatment annual report 1995, Belfast: CCRU.

Central Statistics Office (1999) Regional Trends 34, London: HMSO.

Colenutt, B. (1997) 'Can town planning be for people rather than property?' in A. Blowers and B. Evans, Town planning in the 21st century, London: Routledge.

Connolly, P. and Keenan, M. (2000) Racial attitudes and prejudice in Northern Ireland, Belfast: Northern Ireland Statistics and Research Agency.

Cormack, R. and Osbourne, R. (1991) Discrimination and public policy in Northern Ireland, Oxford: Clarendon Press.

Council of Europe (1998) Gender mainstreaming: Conceptual framework, methodology and presentation of good practices, Strasbourg: Council of Europe.

CRE (Commission for Racial Equality)/RTPI (Royal Town Planning Institute) (1983) Planning for a multiracial Britain, London: CRE.

CTA (Community Technical Aid) (2000) Response to DoE Draft Equality Scheme (correspondence). 
Davoudi, S. and Atkinson, R. (1999) 'Social exclusion and the British planning system', Planning Practice and Research, vol 14, no 2: $225-36$.

Democratic Dialogue (1995) Social exclusion, social inclusion, Belfast: Democratic

Dialogue.

Department of Economic Development (1999) Strategy 2010: Report by the Northern Ireland Economic Development Strategy, Belfast: DoE(NI).

DoE (Department of the Environment) (1999) PPG12: Development Plans, London: HMSO.

DoE (NI) (Department of the Environment [Northern Ireland]) (1998) Shaping our future: Draft regional strategic framework, Belfast: HMSO.

DoE (NI) (2000) Draft Equality Scheme, Northern Ireland Act 1998, Section 75 Statutory Equality Obligations, Belfast: DoE.

DRD (Department of Regional Development) (2000) Draft Equality Scheme, Northern Ireland Act 1998, Section 75 Statutory Equality Obligations, Belfast: DRD.

DSD (Department of Social Development) (2000) Draft Equality Scheme, Northern Ireland Act 1998, Section 75 Statutory Equality Obligations, Belfast: DSD.

Ellis, G. (2000) 'Addressing inequality: planning in Northern Ireland', International Planning Studies, vol 5, no 3: 345-64.

Ellis, G. (2001) 'The difference context makes: planning and ethnic minorities in Northern Ireland', European Planning Studies, vol 9, no 3: 339-57.

Equality Commission (2000) Guide to the statutory duties, Belfast: Equality Commission.

Eversley, D. (1990) 'Inequality at the spatial level', The Planner, vol 76: 13-18.

Fairclough, N. (1995) Critical discourse analysis: The critical study of language, London: Longman.
Fenster, T. (1996) 'Ethnicity and citizen identity in planning and development for minority groups', Political Geography, vol 15, no 5: 405-18.

Foucault, M. (1980) 'Truth and power', in C. Gordon (ed) Michel Foucault, power/ knowledge: Selected writings 1972 -1977, Brighton: Harvester: 109-33.

GLC (Greater London Council) (1985) Race and planning guidelines, London: GLC.

Greed, C. (1994) Women and planning: Creating gendered realities, London: Routledge.

Griffiths, R. (ed) (1998) Social exclusion in cities: The urban policy challenge, Bristol: University of the West of England.

Hastings, A. (1999) 'Discourse and urban change: introduction to the special issue', Urban Studies, vol 36, no 1: 7-12.

Healey, P. (1997) Collaborative planning: Shaping places in fragmented societies, London: Macmillan.

Healey, P., McNamara, P. et al (1988) Land use planning and the mediation of urban change, Cambridge: Cambridge University Press.

Hogwood, B.W. and Gunn, L.A. (1984) Policy analysis for the real world, Oxford: Oxford University Press.

Holland, M. (1998) 'Latest attempt to tackle inequality crucial to North Peace', Irish Times, 12 March: 16.

Imrie, R. (1996) 'Equity, social justice and planning for access and disabled people', International Planning Studies, vol 11: 1734.

Irwin, G. and Dunn, S. (1997) Ethnic minorities in Northern Ireland, Coleraine: Centre for the Study of Conflict, University of Ulster.

Kitchin, R. (1998) “'Out of place, knowing one's place": space, power and the exclusion of disabled people', Disability and Society, vol 13, no 3: 343-56. 
Knox, C. (1998) 'Local government in Northern Ireland: emerging from the bearpit of sectarianism?', Local Government Studies, vol 24, no 3: 1-13.

Knox, C. and Hughes, J. (1994) 'Equality and equity: an emerging government policy in Northern Ireland', New Community, vol 20, no 2: 207-25.

Lawless, P., Martin, R. and Hardy, S. (eds) (1998) Unemployment and social exclusion, London: Jessica Kingsley.

Lee, P. and Murie, A. (1999) Literature review of social exclusion, Edinburgh: Scottish Office Central Research Unit.

Levitas, R. (1996) 'The concept of social exclusion and the new Durkheimian hegemony', Critical Social Policy, vol 16: 520.

Livingstone, S. (1999) 'The Northern Ireland Human Rights Commission', Fordham International Law Journal, vol 22, no 4: 1465-98.

Loftman, P. and Beazley, M. (1998) Race, equality and planning, London: Local Government Association.

McCrudden, C. (1986) 'Rethinking positive action', The Industrial Law Journal, vol 15, no 4: 219-43.

McCrudden, C. (1999) 'Mainstreaming equality in the governance of Northern Ireland', Fordham International Law Journal, vol 22, no 4: 1696-775.

McEldowney, J.M. and Sterrett, K. (2001) 'Shaping a regional vision: the case of Northern Ireland', Local Economy, vol 16, no 1: 38-49.

Madanipour, A. (1998) 'Social exclusion and space', in A. Madanipour, G. Cars and J. Allen, Social exclusion in European cities, London: The Stationery Office.

Mageean, P. and O'Brien, M. (1999) 'From the margins to the mainstream: Human rights and the Good Friday Agreement', Fordham International Law Journal, vol 22, no 4: 1499-538.
Morison, J. (1999) 'Constitutionalism and change: representation governance and participation in the New Northern Ireland', Fordham International Law Journal, vol 22, no 4: 1608-26.

Neill, W.J.V. (1998) 'Place visions and representational landscapes: "Reading" Stormont in Belfast and the Palast der Republik in Berlin', Planning Practice and Research, vol 13, no 4: 386-406.

Neill, W.J.V. and Gordon, M. (2001) Shaping our future? The Regional Strategic Framework for Northern Ireland, Journal of Planning Theory and Practice, vol 2, no 1: 31-52.

New TSN Unit (1999) Vision into practice: The first new TSN annual report, Belfast: Corporate Document Services.

NICVA (1996) Missing the target: A critique of government policy on targeting social need in Northern Ireland, Belfast: NICVA.

NIO (Northern Ireland Office) (1998) Partnership for equality: The government's proposals for future legislation (cm 3890), London: HMSO.

O'Leary, B. (1999) 'The nature of the Agreement', Fordham International Law Journal, vol 22, no 4: 1628-67.

O'Reilly, D. and Stevenson, M. (1998) 'The two communities in Northern Ireland: deprivation and ill health', Journal of Public Health Medicine, vol 20, no 2: 161-8.

Osborne, R. D. (1996) 'Policy dilemmas in Belfast', Journal of Social Policy, vol 25, no 2: 181-99.

Osborne, R.D., Gallagher, A., Cormack, R. with Shortall, S. (1997) 'The implementation of the policy appraisal and fair treatment guidelines in Northern Ireland' in E. McLaughlin and P. Quirk (eds) Policy aspects of employment equality in Northern Ireland, Belfast: Standing Advisory Committee for Human Rights. 
Quirk, P. and McLaughlin, E. (1997)

'Targeting social need', in E. McLaughlin and P. Quirk (eds) Policy aspects of employment equality in Northern Ireland, Belfast: Standing Advisory Committee for Human Rights.

Reade, E. (1987) British town and country planning, Milton Keynes: Open University Press.

Rees, T. (1998) Mainstreaming equality in the European Union, London: Routledge.

Riley, F. (1994) 'Monitoring and race equality in planning', in $\mathrm{H}$. Thomas and $\mathrm{V}$.

Krishnarayan, Race, equality and planning:

Policies and procedures, Aldershot: Avebury.

Room, G. (ed) (1995) Beyond the threshold, Bristol: The Policy Press.

RTPI (Royal Town Planning Institute) (1993)

Ethnic minorities and the planning system, London: RTPI.

Sandercock, L. (1998) Towards cosmopolis: Planning for multicultural cities, Chichester: John Wiley.

Sheehan, S. (1995) 'Fair employment: an issue for the peace process', Capital and Class, vol 37, no 1: 71-82.

Shirlow, P. and Shuttleworth, I. (1999) "Who is going to toss the burgers?": social class and the reconstruction of the Northern Irish economy', Capital and Class, vol 69, no 1: 27-46

Smith, D.J. and Chambers, G. (1991) Inequality in Northern Ireland, Oxford: Clarendon Press.

Social Exclusion Unit (2000) National strategy for neighbourhood renewal: A framework for consultation, London: HMSO.

Stewart, P. (1999) 'Northern Ireland between peace and war?', Capital and Class, vol 69: vi-xiv.

Teague, P. and Wilson, R. (1995) 'Towards an inclusive society', in Democratic Dialogue, Social exclusion, social inclusion, Belfast: Democratic Dialogue.
Teles, S.M. (1998) 'Why is there no affirmative action in Britain?', American Behavioural Scientist, vol 41, no 7: 1004-26.

Thomas, H. (1994) 'Hot food take-aways, ethnic minorities and planning control' in $\mathrm{H}$. Thomas and V. Krishnarayan, Race, equality and planning: Policies and procedures, Aldershot: Avebury.

Thomas, H. (1999) 'Social town planning and the planning profession', in C. Greed, Social town planning, London: Routledge.

Thomas, H. and Krishnarayan, V. (1994) "Race" disadvantage and policy process in British planning', Environment and Planning $A$, vol 26, no 12: 1891-910.

Thompson, R. (1990) 'Planning for the havenots', The Planner, vol 76: 10-12

Thornely, A. and Montgomery, J. (eds) (1990) Radical planning initiatives: New directions for urban planning in the 1990s, Aldershot: Gower.

Turok, I., Kearns, A., et al (1999) 'Social exclusion - in what sense a planning problem?', Town Planning Review, vol 70, no 3: 363-84.

Yiftachel, O. (1995) 'The dark side of modernism: planning as control of an ethnic minority', in S. Watson and K. Gibson, Postmodern cities and spaces, Oxford: Blackwell.

Young, I. (1990) Justice and the politics of difference, Princeton, NJ: Princeton University Press.

\section{Geraint Ellis}

School of Environmental Planning

Queen's University of Belfast, UK 